\title{
Dissemination of soybean technologies in Jambi
}

\author{
Lutfi Izhar $^{1}{ }^{*}$, Hery Nugroho $^{1}$, Desy Novriati $^{1}$, Yardha $^{1}$, and Salwati ${ }^{2}$ \\ ${ }^{1}$ Jambi Assessment Institute for Agricultural Technology. Jl. Samarinda, Paal V, Kotabaru, Kota \\ Jambi, Jambi, Indonesia. 36128 \\ ${ }^{2}$ Riau Assessment Institute for Agricultural Technology. Jl. Kaharuddin Nasution No.341, Simpang \\ Tiga, Bukit Raya, Kota Pekanbaru, Riau. Indonesia. 28284
}

\begin{abstract}
Jambi province is included in the soybean belt areas and one of the soybean seed production centres in Sumatra. Fulfilling the soybean production demand of the Jambi region also in surrounding provinces, the seed program is one of the main requirement. This paper aims to provide an overview of the soybean seed production program through innovation technologies and dissemination for Jambi. An action research was carried out from 2016 to 2018 in the Tebo and East Tanjung Jabung regions, involving seven breeding farmers, local governments, research centres and other stakeholders. Activities carried out in the form of demonstrations plot, demonstrations farm, and technical assistance activities. The results showed that more than 100 tons of newly soybean certified seeds (Anjasmoro) were distributed from soybean production areas to other areas in Jambi and to other provinces such as: Riau, West Sumatera, South Sumatera and Aceh). Agronomic data and yield parameters in soybean seed activities from research site were showed minor significant differences compare to farmer practices technologies. Some innovation technologies were introduced i.e. good agricultural practices, and good handling practices for soybean seed farmers. Through this activity, soybean seeds are available throughout the year (2016 up to recent).
\end{abstract}

\section{Introduction}

Soybean is one of the strategic national cereal commodities. The soybean self-sufficiency target was the main program of the Indonesian Ministry of Agriculture during 2015-2019 period. One application of the program has carried out in Jambi Province [1]. While continuing in the 2020-2045 period, the Indonesian government through the Ministry of Agriculture has prepared several more realistic soybean self-sufficiency scenarios to be programmed in the future $[2,3]$.

In recent years, the demand for soybeans has continued to increase along with the increasing rate of population growth and the increasing need for feed [4]. Besides being the main source of carbohydrates and protein, soybeans are also the raw material for home industries [5,6]. Efforts to accomplishing national and regional soybean needs are carried out by the Jambi Provincial government [7].

\footnotetext{
* Corresponding author: lutizhar@gmail.com
} 
Jambi is one of the soybean centers in the Sumatra island and is included in the soybean belt areas. Jambi is also one of the soybean seed production centres in Sumatera. However, the availability of soybeans for public consumption and animal feed in Jambi Province still cannot be fulfilled optimally. Undertaking this consumption demand, Jambi province becomes the only provinces in Sumatra which responsible for soybean seed production center to support next soybean seasonal planting in Sumatra. This effort has been started since 2014 and is still running until now. In account, one farmer has received a direct award from the President Republic of Indonesia as one of the main soybean breeders in Indonesia in 2017.

Efforts were made by AIAT Jambi in collaboration with appropriate stakeholders such as Tebo and East Tanjung Jabung regional offices for food and horticulture crops, local agricultural extension agency, agricultural extension officers, Jambi province seed certification institute, food plant, horticulture and animal husbandry office in Jambi province, private parties, farmers and farmer groups in Tebo and East Tanjung Jabung regions for emerging soybean development areas, starting from optimizing the seeds availabilities, mentoring seed self-sufficient villages and seed producers, as well as dissemination of sitespecific innovations and assistance in Jambi [8]. Thus, the purpose of this paper was to provide an overview of soybean seed production program through innovation technologies and dissemination that have been carried out by AIAT Jambi. Some technological innovations have introduced such as newly soybean varieties, planting pattern, seed treatments, minimum tillage, planting, fertilizer recommendation, integrated pest management, harvest and post-harvest technologies for seed preparation, also handling and selecting suitable soybean seed for getting the certificate.

\section{Materials and methods}

On-farm research was carried out in Tebo and East Tanjung Jabung regencies, which both are soybean production centers getting an advisory assistance by AIAT Jambi. The main activity locations include some district such as VII Koto, Sumay, Serai Serumpun in Tebo Region and Berbak district in East Tanjung Jabung Region with land area adjusted to the existing seed production target.

The annual research dissemination was carried out starting form 2016 in the Serai Serumpun and VII Koto districts with a demonstration plot area of 25 ha involving 59 farmers with an area of 150 ha, then in 2017 the activity took place in Koto VII District involving 25 farmers with a land area of 45 ha two seasons planting time. Whereas, in 2018 soybean demonstration plot areas were involved farmers in Tebo and East Tanjung Jabung regions with different planting seasons. The first planting season was carried out in Tebo Regency to support the need for soybean seeds in Sumatra covering an area of more than 35 ha as demonstration plots, while the planting time in East Tanjung Jabung region was 5 ha to support seeds for Tebo region in the next planting season. This system is make Jambi become continuous soybean seed production areas yearly.

Some of the main field activities included breeding field evaluations and propagation of soybean new high yielding variety (VUB) seeds, and selecting the best seed performance in site-specific also addressing community needs. Others activities were carried out in the form of demonstrations plot, field training and meetings, technical assistance and developing farmer institution management as well as socialization/dissemination for program activities and technological innovations, also other dissemination activities which was involved Internet of Things (IoT) or social media.

The activities consisted of production and dissemination of high yielding seeds of superior soybean varieties, increasing the capacity of seed producer farmers in producing soybean seeds and monitoring and evaluation. Data were collected through the determination of several growth parameters and the results were then analyzed statistically to see the 
difference [9]. Data collected such as land area (ha), seed life percentage/vigor (\%), plant height $(\mathrm{cm})$, flower time (days), number of productive branch, number of productive pods, weight of 100 seeds $(\mathrm{gr})$, soybean productions $(\mathrm{kg})$ and number for certificate. In addition to the technical introduction of soybean seed technology, socio-economically data, was carried out through an institutional approach. Several farmer groups were assisted on a regular basis to improve farm management and increase their competence. Social parameters comprised of number of farmers groups assisted, total number of farmers groups members assisted, number of farmers groups members who apply technology, and total applied technology. Other data indicator had also gained such as number of farmer members, number of active members, group meeting activities, collaborative activities in farming, how to sell the soybean product, source of farmer funds, and other group norms or rules indicated. These parameters of the institutional development of farmer groups were analysed according to the conditions that established during the research.

During 2016 up to 2018 assessment program showed that more than 100 tons of soybean seeds were scattered from soybean production centre areas to other areas in Jambi as well as to other provinces. The soybean seeds have also been distributed to around several districts in Jambi, to Aceh, West Sumatera, Riau and South Sumatra.

\section{Results and discussion}

\subsection{Scheme of soybean seed production program}

Jambi Province still puts soybean as one of the mainstay cereal commodities. Currently, the Government of Tebo and East Tanjung Jabung Regency have synchronized activities with national and provincial programs to increase soybean productivity, harvested area and Farming Index. This was to implement a national program launched by Directorate General of Food Crops and IAARD in the form of assistance by extension workers/researchers and seeds production program $[10,11]$, in which AIAT Jambi was involved as a working unit of IAARD.

Supporting soybean assistance and program implementation, mentoring activities by AIAT Jambi were Furthermore, the activities continued with coordination, consultation and synchronization carried out at the Jambi Province level and both Tebo/East Tanjab Regency levels. The widest development of soybeans in several years were located in Tebo Regency with an area of more than 2500 ha, the location was also included in the Development of Soybean Food Plant Areas according to the Ministry of Agriculture decree [12,13].

\subsection{Characteristics of the locations}

In determining the location, there are several districts that has become alternatives for this activity, namely VII Koto, Sumay, Rimbo Bujang and Serai Serumpun. The planting season is usually in February and March for Tebo Regency. Whereas, in East Tanjung Jabung regency soybean areas located in Berbak and Ratau Rasau Districts, in which usually their planting season are between June and July or during the dry season with the expectation that the management conditions for tidal water and river flow can be improved [14].

Several multi-location tests of soybean newly varieties (VUB) have been carried out in Jambi and the highest preference of farmers is on the Anjasmoro variety, because apart from large seeds, the pods are not easily broken. Currently, the average land ownership of soybean farmers is only around 1-2 ha and the workforce is very limited, so there are obstacles when planting and harvesting soybeans in 1-3 days due to limited manpower. The Anjasmoro 
variety did not break its pods even though the harvest was delayed for up to five days so that farmers liked it and the market also wanted this soybean variety type.

\subsection{Performance of the improved soybean seeds}

The performance of soybean plantations in Jambi which was adopted recommendation cultivation technologies was achieved much better than the growth of soybean by own farmers' technologies, even though it had been fertilized with completed Urea, SP-36, and $\mathrm{KCl}$ with the same dose as recommended. The use of good quality seeds, as well as the addition of manure and dolomite are the main causes of differences in plant growth performance [15].

Resulting from the demonstration plot/demonstration farm study in the field involving cooperator farmers and breeders, it showed that there were some differences between agronomical parameters, but in general they are not very significant (Table 1). The selection of Anjarmoro newly variety has gone through several stages of multi-location testing so that in 2017 through field activities, this soybean newly variety seed provides worthy agronomic performance and yields. Followed by the soybean program development in 2018, its growth and development was tending to provide the same interpretation of growth and yield as the previous year. From the respectively two years of activity, the availability of soybean seeds for Jambi and surrounding provinces can be fulfilled optimally. The significant difference was occurred from application of water saturated soybean cultivation pattern technological development that carried out in the tidal swamp area in East Tanjung Jabung Regency which was different from Tebo regency in which soybean is planted in a dry land area [16,17]. Water saturated soybean cultivation pattern was evaluated in Sidodadi farmer group, Simpang Village, Berbak District, Easy Tanjung Jabung Region with an area of 50 ha and assisted of more than 1000 ha soybean areas (Table 2).

Table 1. Anjasmoro soybean seeds propagation and production in Dusun Baru Village, VII Koto District, Tebo Regency, Jambi Province (2017)

\begin{tabular}{|c|c|c|c|c|c|c|c|c|c|c|c|}
\hline No & $\begin{array}{c}\text { Replicati- } \\
\text { ons }\end{array}$ & $\begin{array}{c}\text { Land } \\
\text { area } \\
\text { (ha) }\end{array}$ & $\begin{array}{c}\text { Life } \\
\text { percent- } \\
\text { age (\%) }\end{array}$ & $\begin{array}{c}\text { Plant } \\
\text { height } \\
(\mathrm{cm})\end{array}$ & $\begin{array}{c}\text { Flower } \\
\text { time } \\
\text { (days) }\end{array}$ & $\begin{array}{c}\text { Number of } \\
\text { productive } \\
\text { branch }\end{array}$ & $\begin{array}{c}\text { Number of } \\
\text { productive } \\
\text { pods }\end{array}$ & $\begin{array}{c}\text { Weight } \\
\text { of } 100 \\
\text { seeds } \\
\text { (gr) }\end{array}$ & $\begin{array}{c}\text { Productions (kg ) } \\
\text { tested } \\
\text { passed } \\
\text { pass }\end{array}$ \\
\hline 1 & Block I & 1.0 & 92.0 & 96.9 & 34 & 5 & 112 & 12.6 & 1,300 & 1,000 & 76.93 \\
\hline 2 & Block II & 1.0 & 86.5 & 95.4 & 33 & 4 & 99 & 13.5 & 1,400 & 1,100 & 78.57 \\
\hline 3 & Block III & 1.0 & 88.1 & 97,1 & 32 & 4 & 115 & 12.5 & 1,200 & 900 & 85.00 \\
\hline 4 & Block IV & 1.0 & 90.1 & 89.0 & 34 & 5 & 118 & 14.0 & 1,300 & 1,100 & 84.62 \\
\hline 5 & Block V & 1.0 & 89.5 & 92.4 & 35 & 4 & 114 & 13.2 & 1,300 & 900 & 89.24 \\
\hline
\end{tabular}


Table 2. Anjasmoro soybean seeds propagation and production in Dusun Baru Village, VII Koto District, Tebo Regency, and Simpang Village, Berbak District, East Tanjung Jabung regency, Jambi Province (2018)

\begin{tabular}{|c|l|c|c|c|c|c|c|c|c|}
\hline No & Locations & Vigor (\%) & $\begin{array}{c}\text { Plant } \\
\text { height } \\
\text { (cm) }\end{array}$ & $\begin{array}{c}\text { Flowerin } \\
\text { g time } \\
\text { (days) }\end{array}$ & $\begin{array}{c}\text { Number } \\
\text { of } \\
\text { branches }\end{array}$ & $\begin{array}{c}\text { Number } \\
\text { vigor } \\
\text { pods }\end{array}$ & $\begin{array}{c}\text { Weight } \\
\text { of 100 } \\
\text { seeds } \\
\text { (gr })\end{array}$ & $\begin{array}{c}\text { Passed } \\
\text { certificate } \\
\text { (tons) }\end{array}$ & $\begin{array}{c}\text { Label } \\
\text { number } \\
\text { (exemplars) }\end{array}$ \\
\hline 1 & Dusun baru & 80 & 77.4 & 33 & 5 & 105 & 13.3 & 6.0 & 300 \\
\hline 2 & Dusun baru & 82 & 75.6 & 32 & 6 & 122 & 13.4 & 7.0 & 350 \\
\hline 3 & Dusun baru & 80 & 80.2 & 34 & 4 & 106 & 13.7 & 6.0 & 300 \\
\hline 4 & Dusun baru & 78 & 81.1 & 33 & 5 & 99 & 13.0 & 4.0 & 200 \\
\hline 5 & Dusun baru & 81 & 79.4 & 34 & 3 & 108 & 12.9 & 5.0 & 250 \\
\hline 6 & Dusun baru & 78 & 80.2 & 32 & 4 & 107 & 13.2 & 5.0 & 250 \\
\hline 7 & Desa simpang & 79 & 83.2 & 33 & 4 & 121 & 13.8 & 5.7 & 285 \\
\hline
\end{tabular}

\subsection{The introduced innovations and achievements}

In addition to the introduction of technical innovations in agricultural technology in the field, efforts to assist and disseminate the results of these technologies were also carried out. Dissemination was introduced through the involvement of farmer groups regarding various information on soybean farming development, from land preparation to post-harvest and even marketing access. The institutional empowerment of farmer groups needs to be improved in order to achieve the farmers' welfare [18]. Therefore, Soybean mentoring activities has done in Tebo and East Tanjab regencies by institutional strengthening of farmer groups in farming and marketing of agricultural products. A simple analysis was carried out to see the adoption of soybean technology innovations and in general about $90 \%$ of the soybean technology components were adopted by farmer groups. Only technology components such as integrated pest control needs to be supported more intensively (Table 3 ).

In addition to the adoption of technical innovations for agricultural technology in the field, assistance and dissemination of its innovations' technologies were also carried out. Dissemination was presented through the involvement of farmer groups regarding various information on soybean farming development started from land preparation to post-harvest and even marketing. The institutional empowerment of farmer groups needs to be enhanced in order to achieve the farmer welfare. Therefore, the soybean assistance activities in Tebo and East Tanjab Regency by institutionally strengthening of farmer groups in farming actions as well as in marketing soybean products. Farmer institutions, such as farmer groups and farmer group associations, were greatly affected the smooth and successfulness of soybean cultivation in its production center. Management and coordination between the chairman and members of the farmer will greatly affect the production process [19]. Efforts to assist and support for agricultural farmer institutions are still needed in these two soybean production centers (Table. 4). 
Table 3. Application of site-specific soybean technology in demonstration plot and coverage areas.

\begin{tabular}{|c|c|c|c|c|c|}
\hline No & Technology Components & $\begin{array}{l}\text { Number of } \\
\text { farmers } \\
\text { groups } \\
\text { assisted }\end{array}$ & $\begin{array}{c}\text { Total } \\
\text { number of } \\
\text { farmers } \\
\text { groups } \\
\text { members } \\
\text { assisted } \\
\text { (persons) }\end{array}$ & $\begin{array}{l}\text { Number of } \\
\text { farmers } \\
\text { groups } \\
\text { members } \\
\text { who apply } \\
\text { technology } \\
\text { (persons) } \\
\end{array}$ & $\begin{array}{c}\text { Total } \\
\text { applied } \\
\text { technology } \\
(\%)\end{array}$ \\
\hline \multicolumn{6}{|c|}{ Basic Components } \\
\hline 1 & New superior varieties & 8 & 150 & 150 & 100 \\
\hline 2 & Quality and labeled seeds & 8 & 150 & 150 & 100 \\
\hline 3 & $\begin{array}{l}\text { Provision of Rhizobium } \\
\text { on new land } \\
\text { openings/land that has not } \\
\text { been planted with } \\
\text { soybeans for a long time }\end{array}$ & 8 & 150 & 120 & 80 \\
\hline 4 & $\begin{array}{l}\text { Plant population } \\
\text { regulation }(350,000- \\
500,000 \text { plants } / \mathrm{ha})\end{array}$ & 8 & 150 & 150 & 100 \\
\hline 5 & Integrated pest control & 8 & 150 & 75 & 50 \\
\hline \multicolumn{6}{|c|}{ Optional Components } \\
\hline 6 & Land preparation & 8 & 150 & 150 & 100 \\
\hline 7 & $\begin{array}{l}\text { Fertilizing according to } \\
\text { plant needs }\end{array}$ & 8 & 150 & 100 & 70 \\
\hline 8 & Giving organic material & 4 & 70 & 50 & 40 \\
\hline 9 & $\begin{array}{l}\text { Use of Amelioran on acid } \\
\text { dry land }\end{array}$ & 8 & 150 & 100 & 70 \\
\hline 10 & $\begin{array}{l}\text { Irrigation in critical } \\
\text { period }\end{array}$ & 2 & 40 & 40 & 100 \\
\hline 11 & $\begin{array}{l}\text { Harvest and post-harvest } \\
\text { on time }\end{array}$ & 8 & 150 & 120 & 80 \\
\hline
\end{tabular}

Table 4. Institutional Profile of Cooperative Farmer Groups Soybean Seed Breeding in Jambi Province

\begin{tabular}{|c|c|c|}
\hline \multirow{2}{*}{ Indicator } & \multicolumn{2}{|c|}{ Location } \\
\cline { 2 - 3 } & VII Koto, Tebo & East Tanjung Jabung \\
\hline Number of members & 90 & 30 \\
\hline Number of active members & $34(37.8 \%)$ & $23(76.7 \%)$ \\
\hline Group meeting activities & 2 times/month & 1 time/month \\
\hline Collaborative activities in farming & Mutual cooperation & $\begin{array}{c}\text { Arisan } \\
\text { (social Gathering) }\end{array}$ \\
\hline How to sell the soybean product & Group & Individual \\
\hline Source of funds & Group loan & Self-subsistent \\
\hline Other group norms and rules & $\begin{array}{c}\text { Contribution IDR } \\
2,000 / \text { month }\end{array}$ & Fees IDR $1,500 /$ month \\
\hline
\end{tabular}

Source: primary data analyzed (2018)

In general, Tebo Regency has the highest the soybean areas in Jambi, followed by East Tanjung Jabung. However, in terms of farmer institutions, which were several farmer groups involved in seeding activities, the tendency of farmer groups in the East Tanjung Jabung were 
well organized and more dynamic, active and sufficiently manage. This encouraged the development of soybean seeds that were better from a management point of view. Whereas, it required more intensive guidance to improve the dynamics of farmer institutions in Tebo Regency.

Dissemination is carried out not only on farm, but also off farm. This off farm was carried out through publication and dissemination of information through printed materials and other electronic materials with involving social media on the website. Several information technology materials related to the development of soybeans have been spread (Table 5). Therefore, the dissemination materials will be updated and distributed to users gradually and continuously [20].

Table 5. Publication materials as technological dissemination method to support soybean technology assistance activities in Tebo Region.

\begin{tabular}{|c|c|c|c|c|}
\hline No. & Publication Title & $\begin{array}{l}\text { Number } \\
\text { (exemplars) }\end{array}$ & $\begin{array}{l}\text { Type of } \\
\text { publication } \\
\text { distributed }{ }^{1)}\end{array}$ & Recipient $\left.{ }^{2}\right)$ \\
\hline 1 & $\begin{array}{l}\text { Soil processing innovation } \\
\text { technology }\end{array}$ & 3 & brochure & f. Farmer group \\
\hline 2 & $\begin{array}{l}\text { Description of superior soybean } \\
\text { varieties }\end{array}$ & 3 & $\begin{array}{l}\text { brochures and } \\
\text { files }\end{array}$ & $\begin{array}{l}\text { e. Extension agent } \\
\text { f. Farmer group }\end{array}$ \\
\hline 3 & $\begin{array}{l}\text { identification of nutrient problems } \\
\text { for soybeans }\end{array}$ & 3 & $\begin{array}{l}\text { brochures and } \\
\text { files }\end{array}$ & $\begin{array}{l}\text { e. Extension agent } \\
\text { f. Farmer group }\end{array}$ \\
\hline 4 & $\begin{array}{l}\text { pests/diseases and nutrient } \\
\text { problems in soybeans }\end{array}$ & 50 & $\begin{array}{l}\text { brochures and } \\
\text { files }\end{array}$ & $\begin{array}{l}\text { e. Extension agent } \\
\text { f. Farmer group }\end{array}$ \\
\hline 5 & $\begin{array}{l}\text { Soybean production technology in } \\
\text { Jambi's acid dry land }\end{array}$ & 100 & leaflet & $\begin{array}{l}\text { e. Extension agent } \\
\text { f. Farmer group }\end{array}$ \\
\hline 6 & $\begin{array}{l}\text { Procedure for taking composite } \\
\text { soil samples for soil fertility } \\
\text { analysis }\end{array}$ & 3 & brochure & f. Farmer group \\
\hline 7 & $\begin{array}{l}\text { General guidelines for the } \\
\text { production and distribution of } \\
\text { soybean-sourced seeds }\end{array}$ & 5 & $\begin{array}{l}\text { brochures and } \\
\text { files }\end{array}$ & $\begin{array}{l}\text { e. Extension agent } \\
\text { f. Farmer group }\end{array}$ \\
\hline 8 & $\begin{array}{l}\text { Guidelines for soybean cultivation } \\
\text { techniques in various agro- } \\
\text { ecosystem areas }\end{array}$ & 5 & $\begin{array}{l}\text { brochures and } \\
\text { files }\end{array}$ & f. Farmer group \\
\hline 9 & $\begin{array}{l}\text { Production Technology of } \\
\text { soybean, peanut, mung bean, } \\
\text { cassava and sweet potato }\end{array}$ & 5 & brochure & f. Farmer group \\
\hline 10 & $\begin{array}{l}\text { Compost and techniques making } \\
\text { local micro organism }\end{array}$ & 5 & $\begin{array}{l}\text { brochures and } \\
\text { files }\end{array}$ & $\begin{array}{l}\text { e. Extension agent } \\
\text { f. Farmer group }\end{array}$ \\
\hline 11 & Pajale technology package & 50 & brochure & f. Farmer group \\
\hline 12 & Soybean cultivation & 30 & brochure & $\begin{array}{l}\text { e. Extension agent } \\
\text { f. Farmer group }\end{array}$ \\
\hline 13 & Soybean seed technology & 40 & pocket book & $\begin{array}{l}\text { e. Extension agent } \\
\text { f. Farmer group }\end{array}$ \\
\hline 14 & $\begin{array}{l}\text { How to control soybean } \\
\text { pests/diseases }\end{array}$ & 30 & brochure & $\begin{array}{l}\text { e. Extension agent } \\
\text { f. Farmer group }\end{array}$ \\
\hline
\end{tabular}


Dissemination of soybean seeds was not only carried out using a technical approach in the field, but also implemented additional knowledge through the provision of printed media and information of more than 14 titles with sources ranging from books, brochures, leaflets and others. it aimed to increase the competence and interest of farmers to become soybean plant breeder seeds.

Soybean commodity development in Jambi through legal certainty in the form of regional selection for national strategic commodity development areas, technically conducting sitespecific technology assessments involving cooperative farmers and breeders, and developing farmer groups, as well as efforts to disseminate soybean information technology to all users $[21,22]$. Through these activities, soybean farming has developed well and Tebo Regency has become one of soybean seed production centers for supporting the central part of Sumatra soybean production areas. Therefore, consumer needs for soybean products can be fulfilled properly and food security in this areas is getting stronger.

\section{Conclusions}

Technical assessment and assistance for soybean development from upstream and downstream had been carried out by AIAT Jambi. Currently, the activities are still continuing and making Tebo Region as a center for soybean seed production in Central Sumatra. Through on-farm and off-farm accomplishments, fostering and mentoring of breeder farmer groups has carried out by AIAT Jambi starting from seed technology, cultivation, harvesting, post-harvest as well as improving the administration of farmer groups so that the supply of seeds from outside the region can be reduced or even eliminated. Through this activity, soybean seeds are available throughout the year and the target of soybean production to meet the needs of consumers in Jambi and its surroundings can be achieved optimally.

The ability and capacity of breeder farmers have been increasing significantly, this can be seen from the success of producing soybean seeds and getting awards as the best breeder group in Jambi Province and nationally. Furthermore, the existing soybean farming system allows the food security of the Tebo region and Jambi province to be stronger and more sustainable.

Acknowledgments: The authors acknowledge Indonesian Agency for Agricultural Research and Development for financing this research. We also express our recognitions to the Tebo Food Crops and Horticulture Office, Head of Agricultural extension center and the extension workers in all districts involved. Thank you very much also stated to Irmawan S. Ginting, M. Yusuf, Tanius and the Karya Jaya farmer group association presided by Sopyah Hadi. We express our highly gratitude to Bahtiar, Teguh and Senan as district soybean seed farmer groups.

\section{References}

1. Badan Penelitian dan Pengembangan. Rencana Strategis Badan Litbang Pertanian Kementrian Pertanian p 63 (2019)

2. Balitkabi. Teknologi kedelai PUI Aneka Kacang dan Umbi Badan Penelitian dan Pengembangan Penelitian p 19 (2018)

3. Suharyon and Yardha. Ketersediaan teknologi dan prospek pengembangan kedelai di Provinsi Jambi In Bunga Rampai Identifikasi Masalah Untuk Perbaikan Perencanaan dan Program Pembangunan Pertanian CV Kristal Media 978-602-74371-4-2 (2016)

4. Balla PT, MA Hamire, A Wahab, R Asrida, RM Rukka. IOP Conf. Ser. Earth Environ. Sci. 681012054 (2021) 
5. Susanto GWA and N Nugrahaeni. Pengenalan dan Karakteristik Varietas Unggul Kedelai. Bunga Rampai Balai Penelitian Tanaman Aneka Kacang dan Umbi Balitkabi pp 1-12 (2017)

6. Hisjam M, N Oktyajati, W Sutopo, A Ali J. Optimasi Sis. Indus. 192 pp 144-156 (2020)

7. Yardha and N Novita. Teknologi Perbanyakan Benih Kedelai Penerbit Kristal Multimedia ISBN 978-602-71644-4-4 (2016)

8. Nugroho H, L Izhar, Suharyon, N. Imdah. Laporan kegiatan UPBS Kedelai tahun 2019 Balai Pengkajian Teknologi Pertanian Jambi Unpublished p 39 (2020)

9. Ditjentan Pangan 2019 Petunjuk Pelaksanaan Kegiatan Perbenihan Tanaman Pangan Tahun Anggaran. Kementerian Pertanian Jakarta Indonesia p 89 (2019)

10. Widiarta N, NA Subekti, A Harsono, N Nugrahaeni, Marwoto, T Sundari, Y Prayogo, M Azrai, AM Adnan, R Arief, M Aqil, Bahtiar, A Kus, HT Agustiwi. Pedoman Umum Pengembangan Model Kawasan Mandiri Benih Padi, Jagung, dan Kedelai Badan Penelitian danPengembangan Pertanian Kementerian Pertanian. Jakarta p 120 (2015)

11. Surahman M, Ghulamahdi M, Murdianto, Prastowo, S Mardjan, Sutrisno, A Sapei, YJ Purwanto, Y Suharnoto, H Wijaya, Suwarto, U Sehabudin, C Budiman, A Nindita, H Furqoni, AW Ritonga, A Zamzami, S Amarilis, M Rau. Five steps toward the Indonesian soybean self-sufficiency. IOP Conf. Ser. Earth Environ. Sci. 196012044. 10.1088/1755-1315/196/1/012044 (2018)

12. Sayaka B, DKS. Swastika, Y H Saputra. Challenges of soybean self-sufficiency policy in Indonesia. IOP Conf. Ser. Earth Environ. Sci. 648012035 (2021)

13. Darwis V. Warta Penelitian dan Pengembangan Pertanian. Volume 38. 1. ISSN 20164427 (2016)

14. Handayani L, A Rauf, Rahmawaty, T Supriana. IOP Conf. Ser. Earth Environ. Sci. 122. 01. doi :10.1088/1755-1315/122/1/012018 (2018)

15. Fuadi NA, MY J Purwanto, A Fajar. Jurnal Irigasi. 15. 2. 85-94 (2020)

16. Jambo IJ, JCJ Groot, K Descheemaeker, M Bekunda, P Tittonell. NJAS-Wageningen J. Life Sci. 89, 100306 DOI:10.1016/j.njas.2019.100306 (2019)

17. Bachtiar M, M Ghulamahdi, M Melati, D Guntoro, A Sutandi. J. Penel. Pert. Tan. Pang. 35. 3. 2017-227 (2016)

18. Rozi F. Readiness of Soybean in Tidal Land Facing The Agriculture Industry 4.0 In Proceedings The $4^{\text {th }}$ International Conference on Green Agro-Industry 22-23 Oktober 2019 Grand Inna Malioboro (2020)

19. Bopp and A Engler. J. Environ. Mgt. 244.320-327 DOI:10.1016/j.jenvman. 2019.04.107 (2019)

20. Susilawati PN, Kardiyono, A Fauzan, Y Astuti, H Mutmainah, Z Yursak. Introduction of Dryland Soybean Technology in Pandeglang Regency Banten IConARD 2020 E3S Web of Conferences 23203015 (2021)

21. Sendhil R, A Kumar, AK Sharma, P Jasrotia, OP Gupta, RP Meena, S Singh, GP Singh. Strengthening Value Chain in Wheat and Barley for Doubling Farmers Income. Directorate of Extension Department of Agriculture Cooperation \& Farmers Welfare and ICAR-Indian Institute of Wheat and Barley Research. pp 1-144 (2018)

22. Mayasari K, P Muljono, A Fatchiya. American Journal of Humanities and Social Sciences Research (AJHSSR) e-ISSN :2378-703X 43 pp 08-14 (2020) 